\title{
Research on the Combination of Chinese Teaching and Moral Education for Ethnic Preppies
}

\author{
Xiaoling Liu \\ School for Nationalities \\ Huanghe Science and Technology College \\ Zhengzhou, China
}

\begin{abstract}
Chinese teaching is an important and required course for ethnic preppies in the preparatory stage. At present, it is also the exam-compulsory course for preppies in national general examination for students from various schools. Ideological and political education is the main line of education for ethnic preppies in the preparatory stage. In order to combine Chinese teaching with moral education, teachers can express and transmit moral education in Chinese class, making students excavate and understand moral education through assignments. The teaching and the moral education can be combined and promoted each other.
\end{abstract}

Keywords-ethnic preppies; Chinese teaching; moral education

\section{INTRODUCTION}

It is important to integrate Chinese discipline in moral education in teaching activities. However, according to researches on ethnic preparatory education, the research emphasis of Chinese teaching for ethnic preppies rests on teaching pattern, reform and practice. Although the researches on combination of Chinese teaching and moral education have obtained achievement, it is not systematic. Scholars pay attention to teachers and students in teaching process instead of discussing and researching discipline competition and campus culture. There are few countermeasures for the new characteristics of students under new curriculum standard. Furthermore, it is not in-depth in delivery, perception, internalization and practice.

We mainly research how to integrate moral education in Chinese culture to strengthen students' identity of Chinese nation and correctly guide their thoughts through equality of nationality. In this way, we can train high quality preppies to inherit traditional Chinese culture.

\section{CONTENTS OF MORAL EDUCATION FOR ETHNIC PREPPIES}

It clearly proposes in the Outline of the National Medium and Long Term Education Reform and Development Plan that "The acceleration of development of ethnic education pursuit has profound significance on promoting economic and social development of minority and minority areas as well as concerted struggle, prosperity and development of each nation." Meanwhile, the Outline emphasizes the education pursuit of our country must "center on morality, ability and integrated development and care for people" and emphasizes "the full implementation of quality-oriented education is the strategic theme of educational reform development, the demands of the time to fulfill the party's educational policy. It focuses on solving the major issues of training what kind of people and how to train them. It is for all the students, promotes their integrated development and improves their sense of social responsibility to serve the country and the people, the innovative spirit of daring to explore as well as the practical ability to solve problems". According to contents of traditional moral education and reality of ethnic preppies, we establish the principle of ideological and political education: patriotism, love the party, responsibility, gratitude, national harmony, excellent in character and learning and put moral education in the first place. The contents of moral education include the Marxist ethnic theory, national ethnic policy and national unity. It teaches students to love the socialist motherland, support the leadership of the communist party of China and set up the ideas of "Five Outlooks (outlooks on nation, nationality, history, culture and religion)" and "Four Identifications (identifications of the great motherland, the Chinese nation, the Chinese culture and the road of socialism with Chinese characteristics)" and "Three Inseparability ("ethnic minorities cannot separate from the Han nationality, the Han nationality cannot separate from ethnic minorities and ethnic minorities are inseparable from each other". In this way, preppies can become socialist builders and successors reliable in politics with lofty ideals, integrity, knowledge and a strong sense of discipline and moral, intellectual, physical and aesthetic development.

\section{TEACHING MEANS OF MORAL EDUCATION FOR ETHNIC PREPPIES}

At present, the means of moral education in colleges are as follows: open related courses; achieve the construction of campus culture; organize rich activities in the second classroom; hold essay competition with distinct theme; participate in activities organized by the Ministry of Education. It can enrich students' theory and make them apply the knowledge to practice and deepen the impression. 


\section{RESEARCH ON INFILTRATION METHOD OF MORAL EDUCATION IN CHINESE TEACHING ACTIVITIES}

\section{A. Expression and Transmission}

Former French president d'Estaing once said, "The unification of China is consolidated by language. It is written language instead of varied spoken language. It is the unified famous Chinese characters". The classroom of Chinese discipline is an important part of preparatory education and bears the task of transmitting traditional Chinese culture. The academic education and the ideological and political education of preppies are equally important. It will be conducive to teaching activities through combining teaching and moral education and making the purpose of moral education in Chinese teaching for preppies. Besides, teachers of Chinese discipline can be guided to integrate moral education in teaching activities and enrich the theory of preparatory teaching and scientific research.

Teachers of Chinese discipline have heavier responsibility. on Nov. 12, 2009, on the phase IV national training conference on moral education and ideological and political education in mainland high school and preparatory school under cooperation plan held in Urumqi, Lu Xin, the Vice Minister of Education and Erkenjiang Tulahong, member of the standing committee of the party committee in the autonomous region make important speeches by representing the Ministry of Education, the party committee and the people's government of the autonomous region respectively. Lu Xin repeatedly emphasizes, "Moral education and ideological and political education should be the priority among priorities for preppies in cooperation plan. The ideological and political education should be prior to the learning of professional course". "From now on, the moral education and the ideological and political education should adhere to 'Four Identifications (identifications of the great motherland, the Chinese nation, the Chinese culture and the road of socialism with Chinese characteristics)' and 'Five Outlooks (outlooks on nation, nationality, history, culture and religion)' ". When teaching ancient literature in class, teachers can combine the knowledge related to ancient history of China to let students realize the status of our nation on human history. In the College Chinese specifically for preppies, the first unit tells the ancient Chinese literature, including the famous works of patriotic poets, like Du Fu's the Mood of Autumn and Su Shi's A Riverside Town. On one hand, teachers can introduce the composition background to let students understand the author's situation at that time; on the other hand, they should guide students to actively find the emotional factors in the poetry. For example, in the Mood of Autumn, the sad and desolate autumnal scenery makes people have sad and dreary emotion. At this time, teachers should guide students to think. As a patriotic poet, Du $\mathrm{Fu}$ not simply reappear the autumnal scenery. So students can capture the inherent spirit. The society is turbulent, desolate and dark. It vividly shows the extreme anxiety, worries, and resentment of the poet and symbolizes the changeable situation and worrying prospect. The two lines of verse include the late autumnal scenery in the gorge, the sadness of the poet and the disturbance of the country. It is easy for students to understand the theme by reminding them the verse of $\mathrm{Du} \mathrm{Fu}$ learnt by them before. The course is not over. Teachers should raise the questions at a deeper level: why Du Fu takes the mournful autumn as the main theme in the poet and why he is different from the rest in feeling sad with the coming of autumn. It can guide students to think deeply and internalize and sublimate $\mathrm{Du}$ Fu's affective experience. The patriotism education is achieved successfully in teaching. When reading sections in Wang Huairang's I am Proud of Being a Chinese, students are passionate. When teachers ask students how to love our country, some want to study hard and construct the hometown; some want to learn from foreigners to compete foreigners; some shout that we will punish whoever offend our Chinese nation, no matter how far away they are. It is sonorous and forceful and shows their lofty sentiments. No preach can compare with students' experience and no emotional impact can compare with emotional experience of students. The selection of text pays attention to the infiltration of students' moral education.

\section{B. Excavation and Self-Understanding}

The training of "Five Outlooks" runs through the preparatory education. The education of "Four Identifications" is the main line of preparatory education. Therefore, it is far from enough by only depending on the classroom. It is effective means to effectively use all teaching links, deepen moral education and influence students subtly, letting them excavate and experience independently.

Effective assignments can assist classroom teaching and check the effect of it. Experienced teacher can appropriately give assignments in or after class to let students internalize the knowledge and sublimate the emotional experience. The Selected Works of College Chinese Reading and the Simultaneous Exercises of College Chinese which are the supporting teaching materials of the College Chinese can meet students' extracurricular reading and self-excavation. The contents of the selected works of reading involve thought, truth, independence, freedom, justice, conscience, dignity, integrity, science, wisdom, mercy, sympathy, friendship, love, family affection, human feelings, nature and innocence. These articles are excellent literary works at all times and in all over the world. It contains knowledge connotation of human culture and involves many fields, inheriting the excellent cultural tradition as well as covering the essence of modern culture. Students are influenced by the excellent humanistic atmosphere through seriously reading and thinking the teaching materials. The moral education integrates in the process of training humanistic quality. The good human feelings can make people perfect and rational.

The questions on the Simultaneous Workbook of College Chinese also have educational significance. The examples are as follows. The first one, in the lesson of Celebrate Life, "he" is not a person but represents all the people with strong vitality and praises the strong life of human. The author hopes all the people can have the persistence and perseverance, courage and tenacity like "him". It can cultivate students. The second one, O'Neill's drama Beyond the Horizon shows the failure of idealist in reality and the failure of realist in ideal. Why do we have to live and strive since we have already been doomed to fail? What does O'Neill want to tell us? Wouldn't the work bother students and let them have a sense of decadence? It is 
more important for assignments to let students find the positive part in it. Although this is our life, fortunately we are still one the way. No matter what is waiting for us ahead, more importantly, we have the courage to keep moving. It helps to shape students' values and outlook on life. The third one, in the Buck with Seven Horns, the story about the boy and the deer shows the change of relationship between him and his stepfather and the harmony between human and nature. The fourth one, as the master work of "root-seeking novels", the Champion Chess Player leads readers to review and dig the traditional Chinese culture through shaping the image of Wang Yisheng. If students find the "Vulgarity" of eating and the "Elegance" of playing chess of Wang Yisheng, they will understand the sentence said by A Cheng, "People often start from zero and become zero in the end. The history will move forward a step". It can improve students' sense of self-identity and help them to find the position in the society with soaring development. Students will instinctively resist the behaviors in society like unrealistic competition and money worship. It can reduce the abnormal idea of students.

The infiltration of moral education shall run through the education, so that it can train high quality talents with integrated development to devote to the nation and the realization of the great national rejuvenation and Chinese dream. Chinese teaching bears important task in moral education. More effective educational effects will achieve if we combine them together.

\section{CONCLUSION}

The preparatory education in colleges is embodiment of national ethnic policy in higher education to promote the sustainable and healthy development of economy and culture in remote national minority areas. The ethnic preparatory education is the need of harmonious development of our country and national unity. It is of vital importance to maintain national reunification, prolonged stability and prosperity for all the nationalities. The preparatory education should train talents with firm thought and correct direction to benefits the nation and the people.

\section{REFERENCES}

[1] The Central Committee of the Communist Party of China, the State Council. Opinions on Further Strengthening and Improving College Students' Ideological and Political Education [R], Aug.26, 2004

[2] Luo Xiaorong. Characteristics of College Students' Psychological Transformation and Countermeasures [J], Journal of Nanning Polytechnic, 2002(4)

[3] Li Shiguang. Psychological Features of Ethnic Preppy and Educational Management [J], Nationalities Research in Qinghai, 2006(3)

[4] Song Taicheng. Training Mode of Ethnic Preparatory Education and Practice [J], Heilongjiang National Series, 2005(1)

[5] Liu Xiaoyong. Research on Ideological and Political Education of Ethnic Preppies in Universities of Inner Mongolia [D], Inner Mongolia University of Science and Technology, 2001 (6)

[6] Xu Yingying. Discussion on Logical Ecology of "Five-dimension Education" in Ethnic Preparatory Education [J], Journal of Huaiyin Teachers College, 2011(4)
[7] Peng Jun, Kahal Ahmatjan, Umair Amatjan, Discussion on Moral Education in Preparatory Course of Chinese Teaching [J], Journal of Xinjiang Education Institute, 2006(9)

[8] Li Sumin. Infiltration of Moral Education in Chinese Teaching [J], Subject Teaching Exploration, 2003, (3)

[9] Li Fengneng. Infiltration of Moral Education in Chinese Teaching [J], Learning Method Newspaper, Teaching and Research Weekly, 2011, (39)

[10] Xu Changying. Infiltration of Moral Education in Chinese Teaching [J], Research of Modern Basic Education, 2011, (2)

[11] Yan Haiyong. Reflection on Chinese Teaching in Primary School and Moral Education Infiltration [J], Youth Literator, 2009, (14), Shenzhou Education

[12] Gan Lirong. Discussion on Infiltration of Moral Education in Chinese Teaching [J], Educational Reform and Practice, 2012, (2)

[13] Teng Xing, Su Hong, Multi-cultural Society and Pluralistic-integrative Education, Journal of Research on Education, 1997(1) 